Revista IBERC

v. 4, n. 3, p. 125-146, set./dez. 2021

www.responsabilidadecivil.org/revista-iberc

DOI: https://doi.org/10.37963/iberc.v3i2.183

\title{
DESCUMPRIMENTO DO DEVER DE FIDELIDADE RECÍPROCA E O JULGAMENTO DO AGINT NO ARESP 1673702/SP: CONCLUSÃO DA HUMILHAÇÃO COMO ISOLADA E EXTRA CAUSA CONFIGURADORA DO DANO IMATERIAL
}

\author{
BREACH OF MUTUAL FIDELITY AND THE JUDGMENT OF AGINT IN ARESP 1673702/SP: \\ CONCLUSION OF HUMILIATION AS AN ISOLATED AND EXTRA CONFIGURING CAUSE OF \\ INCIDENTAL DAMAGE
}

Felipe Cunha de Almeida ${ }^{i}$

\begin{abstract}
RESUMO: Estes comentários analisaram julgamento proferido pelo Superior Tribunal de Justiça que ligou a existência da humilhação como critério para a condenação por danos imateriais em decorrência da violação ao dever de fidelidade recíproca.
\end{abstract}

Palavras-chave: recurso especial; fidelidade recíproca; violação; humilhação; dano imaterial.

\begin{abstract}
These comments analyzed the judgment handed down by the Superior Court of Justice that linked the existence of humiliation as a criterion for the conviction for immaterial damage as a result of the violation of the duty of reciprocal fidelity.
\end{abstract}

Keywords: special resource; reciprocal fidelity; violation; humiliation; immaterial damage.

SUMÁRIO: 1. Introdução. 2. Responsabilidade civil na perspectiva da proteção da pessoa humana. 3. Antijuricidade, ilicitude, deveres pessoais do direito de família e dano. 3.1. Dano imaterial, previsão constitucional e infraconstitucional. 4. Gravidade da ofensa de forma objetiva: da lesão interesse constitucionalmente previsto. 5. Julgamento do AGINT no ARESP 1673702/SP. 6. Conclusão. Referências.

\section{INTRODUÇÃO}

O casamento, podemos afirmar, é muito mais do que duas pessoas prestando um compromisso perante a lei e também entre si: é comunhão de vida, é formação de uma família, dentre alguns valiosíssimos aspectos. Entendemos, portanto, que o casamento é um modo de existir enquanto cônjuge, enquanto ser individualizado e único, dentro e para a família. É projeto de vida.

\footnotetext{
' Mestre em Direito Privado pela Universidade Federal do Rio Grande do Sul. Advogado e parecerista, com atuação no direito privado e processual civil. Especialista em Direito Civil e Processual Civil com ênfase em Direito Processual Civil. Associado ao IBERC - Instituto Brasileiro de Estudos de Responsabilidade Civil, ao BRASILCON e ao IBDFAM. - Instituto Brasileiro de Direito de Família. É professor de graduação na FACCAT e de cursos de Pós-Graduação (Especialização) do UniRitter, Unisinos, ESA OAB/RS (também Coordenador e integrante da Comissão de Ensino Jurídico), UCS, Verbo Jurídico, Escola Superior da Defensoria Pública/RS, URI Erechim, entre outras instituições. Atuou como professor na graduação ULBRA e PUC. Graduado em Direito pelo Centro Universitário Ritter dos Reis. Autor de diversos livros, capítulos de livros, artigos, com citações pelo Superior Tribunal de Justiça e outros Tribunais estaduais. E-mail: escritoriof.felipe@terra.com.br / ORCID: https://orcid.org/0000-0002-8563-3821
} 
O casamento propicia vermos formalizada, por livre e espontânea vontade, duas vidas se unindo e continuando verdadeira caminhada, com respeito às liberdades e individualidades de cada um. Também é verdade que, no decorrer da dita caminhada, os planos podem, por muitas vezes e pelos mais variados motivos, se alterarem, os sentimentos mudarem, e a relação ter seu término.

Veremos mais adiante que a Constituição e a lei protegem a pessoa enquanto merecedora da tutela de seus interesses com base no princípio da dignidade da pessoa humana. Os interesses que veremos guardam relação direta com o Direito de Família, a Responsabilidade Civil e a dignidade, atrelados ao dever de fidelidade recíproca, previsto no casamento.

De sorte que o (a) estudioso (a) do tema pode perceber, ao ler o título destes comentários, que a palavra conclusão lá está inserida; e propositalmente. E fazemos estas breves explicações introdutórias no sentido de não querer induzir, apenas pela leitura do título, que o Superior Tribunal de Justiça chegou à determinada conclusão comentários, e sim, que da leitura do julgamento que vamos analisar, por nossa e risco, que chegamos à conclusão sofre o critério da humilhação, para fins da possibilidade de condenação por danos imateriais em decorrência da violação do dever de fidelidade recíproca, conforme virá a fundamentação naquele sentido.

Nosso objetivo e problematização é pesquisar se a causa do dano imaterial, para a hipótese de descumprimento do dever de fidelidade, segundo o entendimento do Superior Tribunal de Justiça, em acórdão específico, deve passar pela análise da conduta antijurídica (o descumprimento da lei), ou se há situação diversa (para além, portanto, da antijuricidade). Por analogia ao que acontece com os experimentos científicos, em muitos casos, algo é colocado às lentes de um microscópio no sentido de se ver mais profundamente o que os olhos humanos não conseguem, sozinhos, enxergar. Em nosso microscópio, relativo ao presente trabalho, serão colocados o descumprimento do dever de fidelidade recíproca e o fato humilhação, à luz da dignidade da pessoa humana, conforme vamos desenvolver, para então chegarmos às conclusões acerca do problema trazido.

Pois bem, além do princípio da dignidade da pessoa humana, há também outro princípio de extrema importância para o Direito de Família: o princípio da afetividade. Tal princípio, segundo os estudos de Paulo Lôbo, vem refletido na Constituição Federal (art. 226, parágrafo sexto) e, dentre suas diversas funções, importa respeito aos direitos fundamentais, sintonizando-se com a solidariedade ${ }^{1}$. A palavra respeito, assim entendemos, é de suma importância para o desenvolvimento destes comentários.

Em existindo a afetividade real seja entre cônjuges seja entre companheiros (a), haverá implicações na convivência do casal, pois une as pessoas com o objetivo de constituição de família. ${ }^{2}$ Por outro lado, o descumprimento do dever de fidelidade recíproca precisa ser estudado de forma que contemple o todo em sede da ordem jurídica, e não apenas como um fato isolado. Para tanto, entendemos necessário, conforme se observa dos tópicos que contemplam o sumário, e também por razões dogmáticas e pedagógicas (antes, portanto, de colocar o julgado do STJ no microscópio), de

${ }^{1}$ LÔBO, Paulo. Direito civil: famílias. 9. ed. São Paulo: Saraiva Educação, 2019, p. 73.

${ }^{2}$ LÔBO, Paulo. Direito civil: famílias. 9. ed. São Paulo: Saraiva Educação, 2019, p. 73. 
explorar, mesmo que brevemente, temas conexos ao casamento, à interpretação da lei, ao nexo de causalidade e o dano, mirando, como fizemos questão dizer outras vezes, a proteção do ser humano enquanto ser existente, dentro do casamento, inserido constitucionalmente no Direito de Família ${ }^{3}$.

O dever de fidelidade recíproca é estabelecido pelo Código Civil: está, portanto, positivado em nosso ordenamento, mas, será que basta estar positivado para que o seu descumprimento gere alguma sanção, consequência? Qual seria a ratio da lei, em sede dos deveres pessoais do casamento e, em especial, o dever que vamos experimentar decifrar?

Dentre as classificações da doutrina, segundo a intensidade da sanção, Caio Mário da Silva Pereira leciona sobre as denominadas leis imperfeitas: "Leis imperfeitas são as que não se fazem acompanhadas da pena de nulidade do ato, nem de outra punição ao transgressor, procurando, entretanto, o legislador, por outros meios indiretos, obviar à sua contravenção" 4 .

Paulo Nader, a seu turno, faz a seguinte distinção:

\begin{abstract}
Diz-se que uma norma é perfeita do ponto de vista da sanção, quando prevê a nulidade do ato, na hipótese de sua violação. A norma é mais do que perfeita se, além da nulidade, estipular pena para os casos de violação. Menos que perfeita é a norma que determina apenas penalidade, quando descumprida. Finalmente, a norma é imperfeita sob o aspecto da sanção, quando não considera nulo ou anulável o ato que a contraria, nem contenha castigo aos infratores. ${ }^{5}$
\end{abstract}

A Constituição Federal é expressa no tocante à proteção da família ${ }^{6}$ e, em nível de Responsabilidade Civil, também faz previsão quanto à reparação de danos imateriais, e no rol dos direitos fundamentais ${ }^{7}$. Desta premissa, percebemos que a leitura dos deveres pessoais de família, em especial o de fidelidade recíproca e sua violação, não pode ser feita de forma isolada, como a seguir continuaremos a desenvolver, mas, sim e necessariamente, realizada por uma interpretação constitucional do Direito Civil.

\title{
2. RESPONSABILIDADE CIVIL NA PERSPECTIVA DA PROTEÇÃO DA PESSOA HUMANA
}

Tratar a Responsabilidade Civil como autêntica proteção da pessoa humana, especialmente em sede de danos imateriais decorrentes da violação aos deveres pessoais do Direito de Família e,

\footnotetext{
${ }^{3}$ ALMEIDA, Felipe Cunha de. Responsabilidade civil no direito de família: angústias e aflições nas relações famílias. 2. ed. Porto Alegre: Livraria do Advogado, 2019, p. 213.

${ }^{4}$ PEREIRA, Caio Mário da Silva. Instituições de direito civil: introdução ao direito civil: teoria geral do direito civil. V. 01. 29. ed. Atualizado por Maria Celina Bodin de Moraes. Rio de Janeiro: Forense, 2016, p. 93.

${ }^{5}$ NADER, Paulo. Introdução ao estudo do direito. 40. ed. Rio de Janeiro: Forense, 2017, p. 91.

${ }^{6}$ Art. 226. A família, base da sociedade, tem especial proteção do Estado.

${ }^{7}$ Art. $5^{\circ}$ Todos são iguais perante a lei, sem distinção de qualquer natureza, garantindo-se aos brasileiros e aos estrangeiros residentes no País a inviolabilidade do direito à vida, à liberdade, à igualdade, à segurança e à propriedade, nos termos seguintes:

[...] X - são invioláveis a intimidade, a vida privada, a honra e a imagem das pessoas, assegurado o direito a indenização pelo dano material ou moral decorrente de sua violação;
} 
como foco central destes comentários, pela inobservância do dever de fidelidade recíproca, à luz da dignidade da pessoa humana, é tarefa que exige, pelo menos entendemos assim, verdadeira hermenêutica. Inclui, portanto, analisar o Direito como genuína ciência que é, envolvendo fatos inerentes à privacidade de um casal e que, no decorrer do seu casamento, pode então caminhar para um desentendimento e término da relação, justamente pela violação ao dever mencionado. Nesta hipótese, reforçamos que a análise da dignidade da pessoa humana deve ser objetiva, concreta, e não um, vamos dizer assim, "cheque em branco" cujo "portador" fará com a cártula o que quiser e, daí, extrair suas próprias consequências jurídicas. De sorte que analisar a posição do cônjuge para dentro do Direito de Família enquanto ser humano e ao mesmo tempo sujeito de direitos e deveres relativos ao dever de fidelidade, encontrando assim fundamento que justifique a condenação por danos extrapatrimoniais, é nosso objetivo.

Da premissa acima, portanto, queremos evitar, quando do estudo do princípio da dignidade da pessoa humana, como alerta Antônio Junqueira de Azevedo, "[...] o grande desacordo sobre o seu conteúdo" 8 , em termos de concepção daquela tão importante expressão, eis que um dos fundamentos de nosso Direito9.

Bruno Miragem ensina que o Direito vem no sentido de tutelar a pessoa humana, tendo como fim tal desiderato. A Constituição Federal "[...] deve ser considerada o marco do reconhecimento da pessoa humana, de sua dignidade (a dignidade da pessoa humana), assim como os direitos fundamentais de que é titular" 10 .

A dignidade da pessoa humana está intimamente ligada aos direitos da personalidade, conforme as lições de Pablo Stolze Gagliano e Rodolfo Pamplona Filho "o homem não deve ser protegido somente em seu patrimônio, mas, principalmente, em sua essência" ${ }^{11}$. Por esta razão o Código Civil de 2002 destina, em sua parte geral, um capítulo próprio aos direitos de personalidade, afastando-se do perfil patrimonial que a legislação de 1916 apresentava, preocupando-se o ordenamento atual, de forma substancial, com o indivíduo, sintonizando-se com a Constituição Federal ${ }^{12}$.

Em termos de ofensas a direitos da personalidade e dignidade da pessoa humana, assim ensina Fernando Noronha:

${ }^{8}$ AZEVEDO, Antônio Junqueira de. Caracterização jurídica da dignidade da pessoa humana. Revista dos Tribunais, ano 91, v. 797, mar/2002.

${ }^{9}$ Art. $1^{\circ} \mathrm{A}$ República Federativa do Brasil, formada pela união indissolúvel dos Estados e Municípios e do Distrito Federal, constitui-se em Estado Democrático de Direito e tem como fundamentos:

[...]

III - a dignidade da pessoa humana;

$[\ldots]$.

${ }_{10}$ MIRAGEM, Bruno. Direito civil: responsabilidade civil. São Paulo: Saraiva, 2015, p. 176-177.

${ }^{11}$ GAGLIANO, Pablo Stolze; PAMPLONA FILHO, Rodolfo. Novo curso de direito civil: parte geral. v. 1.16. ed. São Paulo: Saraiva, 2014, p. 185.

12 GAGLIANO, Pablo Stolze; PAMPLONA FILHO, Rodolfo. Novo curso de direito civil: parte geral. v. 1.16. ed. São Paulo: Saraiva, 2014, p. 185. 
A primeira categoria de lesões que geram responsabilidade civil em sentido estrito é constituída pelas violações de direitos da personalidade. Estes são os direitos que, pode dizer-se, constituem a versão civil dos direitos fundamentais da pessoa humana, tutelando esta, na esfera privada: têm por objeto salvaguardar o respeito devido ao corpo (vida, saúde), à imagem, ao nome, pensamento, honra, liberdade e mais atributos da pessoa. Os princípios gerais aplicáveis a tais direitos são objeto de expressa previsão nos arts. 11 e s. do Código Civil. ${ }^{13}$

Para a família, Paulo Lôbo diz que a dignidade da pessoa humana "[...] é o núcleo essencialmente comum a todas as pessoas humanas, como membros iguais do gênero humano, impondo-se um dever geral de respeito, proteção e intocabilidade" ${ }^{14}$. A palavra respeito, trazida pelo mestre, entendemos, deve ser observada também para as relações regidas pelo casamento enquanto identificado o dever de fidelidade recíproca. De sorte que se a Constituição tutela a existencialidade de seus componentes ${ }^{15}$, tal proteção não pode fechar os olhos para a condição humana do cônjuge à luz da fidelidade.

Entrando no tema da Responsabilidade Civil, esta, enquanto princípio, nos revela que "[...] a vítima de uma ofensa a seus direitos e interesses receberá reparação por parte do ofensor" ${ }^{16}$, conforme ensina Caio Mário da Silva Pereira. Portanto, quando se analisa determinado fato à luz da Responsabilidade Civil e da Constituição é que deve ser considerada a gravidade da lesão, mas não quanto às consequências, e sim e ao que importa, ao seu objeto enquanto "[...] interesse existencial constitucionalmente garantido" 17 .

O interesse existencial tutelado pela Constituição acima referido pela doutrina é, assim deduzimos, e no tocante ao casamento, a plena expansão do cônjuge enquanto ser que integra o casamento e vê no instituto um meio para o desenvolvimento de suas faces da personalidade. É meio de desenvolvimento da família e do indivíduo que a compõe. Tal condição, evidentemente, pode ser interrompida quando um dos integrantes não tem mais interesse na relação, contudo, quando isto ocorre pelo descumprimento do dever de fidelidade recíproca, a vítima, de forma involuntária, vê sua condição extinguida, configurando então o dano reparável na espécie imaterial.

\section{ANTIJURICIDADE, ILICITUDE, DEVERES PESSOAIS DO DIREITO DE FAMÍLIA E DANO}

Nossa tradição jurídica é marcada pela civil law. É determinada pelas leis, pelos Códigos, sendo que a interpretação daquelas deve vir pautada com base nos valores e princípios trazidos pela Constituição Federal. Pontes de Miranda, inclusive, ensinando sobre a missão do cientista do Direito,

\footnotetext{
13 NORONHA, Fernando. Direito das obrigações. 4. ed. São Paulo: Atlas, 2013, p. 466.

14 LÔBO, Paulo. Direito civil: famílias. 9. ed. São Paulo: Saraiva Educação, 2019, p. 57.

15 LÔBO, Paulo. Direito civil: famílias. 9. ed. São Paulo: Saraiva Educação, 2019, p. 59.

${ }^{16}$ PEREIRA, Caio Mário da Silva. Responsabilidade civil. 10. ed. Atualizado por Gustavo Tepedino. Rio de Janeiro: GZ, 2012, p. 22.

17 SCHREIBER, Anderson. Novos paradigmas da responsabilidade civil: da erosão dos filtros à diluição dos danos.

5. ed. São Paulo: Atlas, 2013, p, 130.
} 
assevera que este deve: "[...] observar, analisar e estudar as relações de responsabilidade e delas induzir as regras" 18 .

Quando se considera o dano e a sua quantificação, deve ter em mente o interprete "[...] o conteúdo geral do sistema, no sector visado, bem como a política da lei, devidamente vertida nas normas a aplicar" 19 .

Se há a previsão do dever de fidelidade inserido no Código Civil, é justamente pelo fato de nosso ordenamento possuir um Código. Claudia Lima Marques, Antônio Herman Benjamin e Leonardo Roscoe Bessa nos levam para o significado dos códigos: "[...] "código" significa um conjunto sistemático e logicamente ordenado de normas jurídicas, guiadas por uma idéia básica [...]"20.

Ora, se tal fato previsto em lei ocorre, sendo sua consequência o dever de reparação, disto o julgador não pode se afastar. Como ensina Pietro Perlingieri: "O fato concreto quando se realiza constitui o ponto de confluência entre a norma e o seu tornar realidade: é o modo no qual o ordenamento atua" ${ }^{21}$. Fernando Noronha, a seu turno, leciona que: "O dano não resulta necessariamente da violação de uma norma jurídica; tal violação pode ou não ocasionar danos" ${ }^{22}$. Daí resulta a necessidade do estudo da violação ao dever de fidelidade recíproca para além dos limites da antijuridicidade, como estamos nos propondo a fazer.

O Código Civil prevê uma série de direitos pessoais aos integrantes da família e, em atenção aos presentes comentários, o dever de fidelidade recíproca entre os cônjuges vem assim expresso: "Art. 1.566. São deveres de ambos os cônjuges: I - fidelidade recíproca; [...]". Em outra oportunidade, falamos sobre a natureza jurídica e a classificação das normas pessoais do Direito de Família ${ }^{23}$, voltando, agora, a continuar o tema, mas em contexto às presentes linhas.

Em relação aos direitos pessoais previstos pelo Código Civil, Orlando Gomes nos diz que aqueles apresentam também um caráter pessoal ${ }^{24}$. E completa: há fundamentos éticos na existência daqueles direitos e, em sede de deveres, apresentam-se, entre outros, como os "[...] direitos pessoais puros [...]"25 ou também denominados de direitos de família puros, justamente por serem pessoais e extrapatrimoniais, trazendo, como exemplo, os deveres pessoais relativos ao casamento ${ }^{26}$. Isto não significa concluir, por outro lado que, quando violados, não surgirá o dever de reparação ${ }^{27}$. Paulo Lôbo,

18 PONTES DE MIRANDA, Francisco Cavalcanti. Tratado de direito privado: parte especial: tomo 53. 1. ed. Atualizado por Vilson Rodrigues Alves. Campinas: Bookseller, 2008, p. 21.

${ }^{19}$ MENEZES CORDEIRO, António. Tratado de direito civil português: direito das obrigações: tomo III: gestão de negócios: enriquecimento sem causa: responsabilidade civil. v. II. Coimbra: Almedina, 2010, p. 747.

${ }^{20}$ MARQUES, Claudia Lima; BENJAMIN, Antônio Herman V; BESSA, Leonardo Roscoe. Comentários ao código de defesa do consumidor. 3. ed. São Paulo: Revista dos Tribunais, 2010, p. 55.

21 PERLINGIERI, Pietro. Perfis do direito civil: introdução ao direito civil constitucional. 3. ed. Tradução de Maria Cristina De Cicco. Rio de Janeiro: Renovar, 2007, p. 90.

22 NORONHA, Fernando. Direito das obrigações. 4. ed. Saraiva, São Paulo, 2013, 497.

${ }^{23}$ ALMEIDA, Felipe Cunha de. Normatividade e interação entre os deveres pessoais do direito de família, as leis imperfeitas e a responsabilidade civil. In: Revista Eletrônica da ESA/RS, Porto Alegre, v. 8, p. 1-20, 2020.

24 GOMES, Orlando. Direito de família. 7. ed. Rio de Janeiro: Forense, 1993, p. 4.

25 GOMES, Orlando. Direito de família. 7. ed. Rio de Janeiro: Forense, 1993, p. 4.

${ }^{26}$ GOMES, Orlando. Direito de família. 7. ed. Rio de Janeiro: Forense, 1993, p. 4.

27 Sobre o tema, convidamos para a seguinte leitura: ALMEIDA, Felipe Cunha de. Normatividade e interação entre os deveres pessoais do direito de família, as leis imperfeitas e a responsabilidade civil. In: Revisa Eletrônica da ESA OAB/RS, Porto Alegre, v. 8, n. 2 (2020). Porto Alegre: ESA/RS, 2021. 
estudando a origem histórica do dever de fidelidade recíproca, ensina que aquele dever era entendido como:

[...] impedimento de relações sexuais com terceiros. Historicamente, voltava-se em grande medida ao controle da sexualidade feminina, para proteger a paz doméstica e evitar a turbatio sanguinis. Nesse sentido estrito, sempre se manifestaram a doutrina e a jurisprudência. Não se confunde, portanto, com o respeito e consideração mútuos. ${ }^{28}$

O dever de fidelidade recíproca, em épocas mais remotas, tinha uma função de, pelo Estado, ver o controle sobre as mulheres e sobre a sua sexualidade, em especial atenção ao patrimônio da família, de forma unitária, "[...] assentado em rígido sistema de legitimidade e sucessão dos filhos, expurgando-se os considerados ilegítimos" 29.

O mestre em referência pondera que o dever ora em estudo tem sua manutenção questionada, pois será verificável apenas "[...] com o sacrifício da intimidade e da privacidade das pessoas [...]"30. De sorte que o dever de fidelidade recíproca, atualmente, deve ser encarado no "[...] plano da consciência moral, uma vez que destituído de consequências jurídicas". ${ }^{31}$ Assim, caso o comportamento de um dos cônjuges não esteja a contento do outro, o divórcio é o instrumento hábil a pôr fim ao vínculo conjugal ${ }^{32}$.

A doutrina, agora enfrentando o estudo do dano, ensina que aquele "[...] passa a ser, então, dimensionado segundo o legítimo interesse daquela que sofreu a repercussão no bem jurídico lesado - interesse estabelecido nos limites da imputação" ${ }^{33}$. De sorte que o dano imaterial é a nossa próxima etapa de estudos, mas sempre atrelado à violação ao dever de fidelidade recíproca.

Insistimos que, em uma leitura isolada da lei, não nos parece que a violação ao dever de fidelidade recíproca levaria para a ilicitude. Contudo, a leitura daquele artigo, como daremos seguimento, jamais poderá vir ilhada.

\subsection{Dano imaterial, previsão constitucional e infraconstitucional}

Sobre o dano extrapatrimonial, este "[...] deve ser compreendido como lesão a um interesse jurídico atinente à personalidade humana e, por isso mesmo, insuscetível de valoração econômica" ${ }^{4}$.

${ }^{28}$ LÔBO, Paulo. Direito civil: famílias. v. 5. 9. ed. São Paulo: Saraiva Educação, 2019, p. 137.

${ }^{29}$ LÔBO, Paulo. Direito civil: famílias. v. 5. 9. ed. São Paulo: Saraiva Educação, 2019, p. 137.

${ }^{30}$ LÔBO, Paulo. Direito civil: famílias. v. 5. 9. ed. São Paulo: Saraiva Educação, 2019, p. 137.

31 LÔBO, Paulo. Direito civil: famílias. v. 5. 9. ed. São Paulo: Saraiva Educação, 2019, p. 138.

32 LÔBO, Paulo. Direito civil: famílias. v. 5. 9. ed. São Paulo: Saraiva Educação, 2019, p. 138.

33 TEPEDINO, Gustavo; TERRA, Aline Miranda Valverde; GUEDES, Gisela Sampaio da Cruz. Fundamentos do direito civil: responsabilidade civil. v. 4. Rio de Janeiro: Forense, 2020, p. 30.

34 SCHREIBER, Anderson. In: SCHREIBER, Anderson; TARTUCE, Flávio; SIMÃO, José Fernando; MELLO, Marco Aurélio Bezerra de; DELGADO, Mário Luiz. Código civil comentado: doutrina e jurisprudência. Rio de Janeiro: Forense, 2019, p. 114 
Há então duas correntes que se contrapõem, quando do estudo do dano imaterial: "a) a corrente subjetiva, que compreende o dano moral como dor, sofrimento e humilhação; e b) a corrente objetiva, que define o dano moral como a lesão a um interesse jurídico atinente à personalidade humana" ${ }^{35}$.

Humberto Theodoro Júnior afirma que se a ordem jurídica considera como valores íntimos da personalidade, deve haver mecanismos de defesa contra agressões que tenham por objeto o plano subjetivo ou moral ${ }^{36}$.

O panorama atual é o da plena possibilidade de reparação de danos de natureza extrapatrimonial, contudo, nem sempre foi assim. Yussef Said Cahali já dizia que a fase atual sobre a discussão já foi superada ${ }^{37}$, ensinando o mestre que "na reciclagem periódica do tema reparação do dano moral, a presente fase é a da superação de antinomias anteriores, com sua consagração definitiva, em texto constitucional e enunciado sumular que a asseguram" 38 .

Sobre os danos extrapatrimoniais e o Código Civil de 2002, ressaltam Pablo Stolze Gagliano e Rodolfo Pamplona Filho que "um dos aspectos positivos da nova Codificação brasileira é justamente o reconhecimento formal e expresso da reparabilidade dos danos morais" ${ }^{39}$. Os mestres apontam, então, para o artigo 186, do Código Civil${ }^{40}$.

Mas afinal, qual seria a natureza jurídica da reparação por danos imateriais? Os estudos de Flávio Tartuce nos dão o rumo, fazendo-nos chegar em um porto seguro a respeito deste tema. É que o mestre nos leva à três correntes doutrinárias e jurisprudenciais, no seguinte sentido:

\begin{abstract}
$1^{a}$ Corrente: A indenização por danos morais tem o mero intuito reparatório ou compensatório, sem qualquer caráter disciplinador ou pedagógico. Essa tese encontra-se superada na jurisprudência, pois a indenização deve ser encarada mais do que uma mera reparação.

$2^{a}$ Corrente: A indenização tem um caráter punitivo ou disciplinador, tese adotada nos Estados Unidos da América, com o conceito de punitive damages. Essa corrente não vinha sendo bem aceita pela nossa jurisprudência, que identificava perigos na sua aplicação. Porém, nos últimos tempos, tem crescido o número de adeptos a essa teoria. Aqui estaria a teoria do desestímulo, desenvolvida, no Brasil, por Carlos Alberto Bittar (Reparação civil..., 1994, p. 219-226.

$3^{a}$ Corrente: $A$ indenização por dano moral está revestida de um caráter principal reparatório e de um caráter pedagógico ou disciplinador acessório, visando a coibir novas condutas. Mas esse caráter acessório somente existirá se estiver acompanhado do principal. Essa tese tem prevalecido na jurisprudência nacional. ${ }^{41}$
\end{abstract}

35 SCHREIBER, Anderson. In: SCHREIBER, Anderson; TARTUCE, Flávio; SIMÃO, José Fernando; MELLO, Marco Aurélio Bezerra de; DELGADO, Mário Luiz. Código civil comentado: doutrina e jurisprudência. Rio de Janeiro: Forense, 2019, p. 114

36 THEODORO JÚNIOR, Humberto. Dano moral. 8. ed. Rio de Janeiro: Forense, 2016, p. 02.

${ }^{37}$ CAHALI, Yussef Said. Dano moral. 4. ed São Paulo: Revista dos Tribunais, 2011, p. 17.

38 CAHALI, Yussef Said. Dano moral. 4. ed São Paulo: Revista dos Tribunais, 2011, p. 17.

39 GAGLIANO, Pablo Stolze; PAMPLONA FILHO, Rodolfo. Novo curso de direito civil: responsabilidade civil. v. 3. 13. ed. São Paulo: Saraiva, 2015, p. 105.

40 GAGLIANO, Pablo Stolze; PAMPLONA FILHO, Rodolfo. Novo curso de direito civil: responsabilidade civil. v. 3. 13. ed. São Paulo: Saraiva, 2015, p. 105.

41 TARTUCE, Flávio. Direito civil: direito das obrigações e responsabilidade civil. v.2. 29. ed. Rio de Janeiro: Forense, 2014, p. 426. 
Mas antes da lei, entendemos que a reparação dos danos imateriais deve passar pela previsão e análise do texto constitucional:

Art. $5^{\circ}$ Todos são iguais perante a lei, sem distinção de qualquer natureza, garantindose aos brasileiros e aos estrangeiros residentes no País a inviolabilidade do direito à vida, à liberdade, à igualdade, à segurança e à propriedade, nos termos seguintes:

$[\ldots]$

V - é assegurado o direito de resposta, proporcional ao agravo, além da indenização por dano material, moral ou à imagem;

$[\ldots]$

X - são invioláveis a intimidade, a vida privada, a honra e a imagem das pessoas, assegurado o direito a indenização pelo dano material ou moral decorrente de sua violação;

É justamente a Constituição que nos direciona à reparação que estamos buscando atrelar à violação ao dever de fidelidade recíproca, agora, como previsão a nível de direito fundamental. Portanto, tanto a dignidade da pessoa humana quanto a reparação encontram previsão constitucional, o que nos exige uma interpretação para além do Código Civil, seguindo a análise a partir do próximo tópico.

\section{GRAVIDADE DA OFENSA DE FORMA OBJETIVA: DA LESÃO A INTERESSE CONSTITUCIONALMENTE PREVISTO}

Anderson Schreiber nos remete à questão importantíssima acerca da análise da caracterização dos danos imateriais. O mestre, fazendo alusão à doutrina e jurisprudência, revela que muitas vezes o entendimento para a configuração do dano extrapatrimonial viria atrelado à análise da gravidade da ofensa. Portanto, há doutrina entendendo que a configuração daquela espécie de dano viria através da percepção de além da lesão a uma situação constitucionalmente prevista ou protegida, pois necessário também a demonstração de lesão grave ${ }^{42}$. As ponderações seguem neste sentido:

Forçoso concluir, portanto, que o termo gravidade quer se referir ao dano não patrimonial em si, isto é, à lesão que a conduta do ofensor representa para a personalidade do ofendido. Ainda assim não parece legítimo distinguir, dentre tais lesões, aquelas que se apresentam como graves e, de outro lado, aquelas que assim não se apresentam, ressarcindo apenas as primeiras. ${ }^{43}$

De sorte que Anderson Schreiber, com suporte na doutrina de Caio Mário da Silva Pereira, conclui que para os danos materiais não se entra no mérito da gravidade da lesão, e, em o fazendo

42 SCHREIBER, Anderson. Novos paradigmas da responsabilidade civil: da erosão dos filtros à diluição dos danos. 5. ed. São Paulo: Atlas, 2013, p. 130.

43 SCHREIBER, Anderson. Novos paradigmas da responsabilidade civil: da erosão dos filtros à diluição dos danos. 5. ed. São Paulo: Atlas, 2013, p. 130. 
para os danos extrapatrimoniais, "[...] representaria inversão axiológica, privilegiando o patrimônio frente à pessoa, por meio do emprego de um critério praticamente quantitativo, que nenhuma base normativa encontra, ao menos no ordenamento jurídico brasileiro" ${ }^{44}$. É o objeto do dano que tem de ser avaliado em sede de gravidade, e não sua intensidade. A análise do dano deve passar pelo estudo do interesse constitucionalmente protegido, tutelado 45 .

José Mosset Iturraspe é claro ao afirmar que fatos que dizem respeito às situações familiares sensibilizam, e muito, os seus integrantes, de sorte que razões não existem para que tais fatos escapem à responsabilidade $\mathrm{civil}^{46}$.

Adriano de Cupis já alertava que os direitos da personalidade, por se constituírem como:

[...] direitos não patrimoniais absolutos", obrigam a todos o seu respeito, melhor dizendo: "Todos os sujeitos compreendidos das normas de direito objetivo das quais derivam os direitos da personalidade; e todos, igualmente, perante o pressuposto das mesmas normas, isto é, perante a existência de um determinado sujeito, estão vinculados à obrigação jurídica de não lesar os direitos da personalidade de que o mesmo sujeito é titular. ${ }^{47}$

Construído o caminho até aqui, vamos então à análise do julgamento proferido pelo Superior Tribunal de Justiça acerca da violação do dever de fidelidade recíproca e os danos imateriais.

\section{JULGAMENTO DO AGINT NO ARESP 1673702/SP}

Toda a análise doutrinária que fizemos até este momento tem por objetivo o estudo da decisão abaixo, que entendeu que para configuração de danos imateriais, as humilhações e constrangimentos ocasionados pelo descumprimento do dever de fidelidade recíproca devem vir provadas:

Ementa: PROCESSO CIVIL. AGRAVO INTERNO. RAZÕES QUE NÃO ENFRENTAM O FUNDAMENTO DA DECISÃO AGRAVADA. AÇÃO DE DIVÓRCIO E INDENIZATÓRIA. INFIDELIDADE COMPROVADA. HUMILHAÇÕES E CONSTRANGIMENTOS PÚBLICOS. DANO MORAL CONFIGURADO. VALOR. R\$ 30.000,00. ALTERAÇÃO. IMPOSSIBILIDADE. REEXAME DE PROVAS. SÚMULA 7/STJ. 1. As razões do agravo interno não enfrentam adequadamente o fundamento da decisão agravada. 2. Admite a jurisprudência do Superior Tribunal de Justiça, excepcionalmente, em recurso especial, reexaminar o valor fixado a título de indenização por danos morais, quando ínfimo ou exagerado. Hipótese, todavia, em que o valor foi estabelecido na instância ordinária, atendendo às circunstâncias de fato da

${ }^{44}$ SCHREIBER, Anderson. Novos paradigmas da responsabilidade civil: da erosão dos filtros à diluição dos danos. 5. ed. São Paulo: Atlas, 2013, p. 130.

45 SCHREIBER, Anderson. Novos paradigmas da responsabilidade civil: da erosão dos filtros à diluição dos danos. 5. ed. São Paulo: Atlas, 2013, p. 130.

46 ITURRASPE, Jorge Mosset. Responsabilidade por daños: el dano moral. Tomo V. Buenos Aires: RubinzalCulzoni Editores, 1971, p. 167.

${ }^{47}$ DE CUPIS, Adriano. Os direitos da personalidade. 2. ed. Tradução de Afonso Celso Furtado Rezende. São Paulo: Quorum, 2008, p. 37 
causa, de forma condizente com os princípios da proporcionalidade e razoabilidade. 3 . Agravo interno a que se nega provimento. ${ }^{48}$

A Corte já também decidiu sobre a necessidade de demonstração de ofensa à honra "ainda que fosse comprovado o adultério pelo apelado, em casos análogos, este Tribunal entende que a infidelidade conjugal, sem a prova de ofensa à honra da parte contrária, não é capaz de gerar o dever de indenizar. (e-STJ, fl. 499)" 49.

Sobre a violação ao dever ora em comentário e o dano imaterial, dentre as várias teorias que buscam explicar o nexo de causalidade, Mafalda Miranda Barbosa nos conduz à doutrina portuguesa a respeito do tema. Neste sentido:

[...] o nexo de causalidade comunga, naquela que nos parece ser a melhor visão do problema, de uma natureza binária. Lado a lado concorrem a causalidade fundamentadora da responsabilidade e a causalidade preenchedora da responsabilidade. ${ }^{50}$

Trata-se, portanto, de uma natureza binária, eis que, por primeiro, avalia-se a ligação entre a conduta do agente à ofensa (ao direito ou interesse) $e^{51}$, a segunda, "[...] liga a lesão do direito ou interesse protegido aos danos consequenciais (segundo dano) verificado" 52.

É verdade que o acórdão em análise, em razão da Súmula 07, não enfrentou a questão em si, contudo, poderíamos pensar, também, na hipótese de recurso especial em relação ao julgamento de origem, pela violação à questão federal (exigência de prova da humilhação no tocante ao dever de fidelidade recíproca, ou então violação à honra, como visto no outro julgamento).

De sorte que entendemos que a violação ao dever de fidelidade recíproca (seja tal violação ocorrida de forma sorrateira ou então a não esconder o fato), guarda sim relação direta com a mais pura negação da condição de cônjuge enquanto ser existente na relação para com o outro. A gravidade quanto ao objeto reside neste fato. Diante de tal circunstância resultaria o dano como ofensa aos direitos de personalidade, justamente por representar o cônjuge um nada para o outro e, disso, resultaria a involuntariedade da continuidade de um projeto de vida, pela vítima. De modo que voltando às lições de Mafalda Miranda Barbosa, quando salienta que "a responsabilidade deixa, nesta

\footnotetext{
48 BRASIL. Superior Tribunal de Justiça. Agravo Interno no Agravo no Recurso Especial $n^{\circ}$ 1673702/SP. Relatora: Ministra Maria Isabel Gallotti. Quarta Turma, julgado em 14/09/2020, DJe 18/09/2020.

49 BRASIL. Superior Tribunal de Justiça. Recurso Especial $n^{\circ} 1887568 / P R$. Relator: Ministro Paulo Dias de Moura Ribeiro. Decisão Monocrática. Julgado em 19/08/2020, DJe 21/08/2020.

${ }^{50}$ BARBOSA, Mafalda Miranda. Causalidade mínima. Revista de Direito da Responsabilidade, Coimbra, ano 1, 2019. Disponível em: http://revistadireitoresponsabilidade.pt/2019/causalidade-minima. Acesso em: 07 jun. 2021. ${ }^{51}$ BARBOSA, Mafalda Miranda. Causalidade mínima. Revista de Direito da Responsabilidade, Coimbra, ano 1, 2019. Disponível em: http://revistadireitoresponsabilidade.pt/2019/causalidade-minima. Acesso em: 07 jun. 2021. 52 BARBOSA, Mafalda Miranda. Causalidade mínima. Revista de Direito da Responsabilidade, Coimbra, ano 1, 2019. Disponível em: http://revistadireitoresponsabilidade.pt/2019/causalidade-minima. Acesso em: 07 jun. 2021.
} 
perspectiva, de ser entendida exclusivamente do ponto de vista dogmático, mas ser compreendida do ponto de vista ético-axiológico" 53. Portanto, em atenção do princípio da responsabilidade:

[...] a chamar à colação a ideia de pessoa livre e responsável, absolutamente diversa do indivíduo dessolidário e solipsita. A pessoa, ao agir, porque é livre, assume uma role responsibility, tendo de, no encontro com o seu semelhante, cumprir uma série de deveres de cuidado. ${ }^{54}$

\section{CONCLUSÃO}

Parece-nos claro que a jurisprudência do STJ vem no sentido de que, para que surja o dever de reparação civil pela violação do dever de fidelidade recíproca, mesmo que tal conduta seja, objetivamente, antijurídica, venha aos autos a efetiva comprovação da humilhação, do constrangimento causado ao cônjuge, de ofensa à honra. De sorte que, apenas então, residiria a ilicitude da conduta.

Contudo, a se perpetuar este entendimento, não teremos como conclusão diversa a de que, se o descumprimento do dever de fidelidade deve ter como consequência causa diversa, tal causa é, por assim dizer, extra, ao dever de fidelidade violado. É, portanto, causa autônoma, isolada.

Com todo o respeito às posições em contrário, não podemos tratar a solução como uma espécie de tudo (necessidade de comprovação de humilhação, por exemplo) ou nada (ausência da prova da humilhação) quando do descumprimento de um dever integrante de um núcleo mínimo, mas, por outro lado, dotado de normatividade enquanto princípio (dignidade da pessoa humana e sua existencialidade negada, enquanto ente familiar). Como ensina Paulo Bonavides "os princípios, uma vez constitucionalizados, se fazem a chave de todo o sistema normativo" 55.

Humilhações, coações, constrangimentos ocorrem em diversas áreas da vida da pessoa humana, e que podem ou não gerar o dever de reparação por ofensa a direitos da personalidade (cobranças abusivas ${ }^{56}$; inscrições indevidas ${ }^{57}$, como alguns exemplos) ou então serem consideradas

${ }^{53}$ BARBOSA, Mafalda Miranda. Causalidade mínima. Revista de Direito da Responsabilidade, Coimbra, ano 1, 2019. Disponível em: http://revistadireitoresponsabilidade.pt/2019/causalidade-minima. Acesso em: 07 jun. 2021. ${ }^{54}$ BARBOSA, Mafalda Miranda. Causalidade mínima. Revista de Direito da Responsabilidade, Coimbra, ano 1, 2019. Disponível em: http://revistadireitoresponsabilidade.pt/2019/causalidade-minima. Acesso em: 07 jun. 2021. ${ }^{55}$ BONAVIDES, Paulo. Curso de direito constitucional. 33. ed. São Paulo: Malheiros, 2018, p, 263.

${ }^{56}$ Ementa: Responsabilidade Civil. Dano moral. Cobrança abusiva. Empresa de cobrança. A forma abusiva de efetuar a cobrança de dívida pode causar dano moral a ser indenizado na forma do art. 159 do CC. Comete ato ilícito a empresa de cobrança que envia carta ameaçando de representação criminal por emissão de cheque sem fundos, quando esse documento não existe. Recurso conhecido e provido. (BRASIL. Superior Tribunal de Justiça. Quarta Turma. Recurso Especial $n^{\circ} 343.700 / P R$. Relator: Ministro Ruy Rosado de Aguiar. Julgado em: 09/04/2002).

${ }^{57}$ Ementa: AGRAVO INTERNO. AGRAVO EM RECURSO ESPECIAL. INSCRIÇÃO INDEVIDA. VERIFICAÇÃO. INVIABILIDADE. NECESSIDADE DE REEXAME FÁTICO. SÚMULA 7/STJ. DANO MORAL PRESUMIDO. VALOR ARBITRADO PELA INSTÂNCIA ORDINÁRIA. PROPORCIONALIDADE E RAZOABILIDADE RESPEITADOS. NÃO PROVIMENTO. 1. Não cabe, em recurso especial, reexaminar matéria fático-probatória (Súmula n. 7/STJ). 2. Nos termos da jurisprudência desta Corte, a inscrição ou manutenção indevida de nome em cadastros de inadimplência acarreta dano moral presumido. 3. A jurisprudência do Superior Tribunal de Justiça admite, excepcionalmente, em sede de especial, o reexame do valor fixado a título de danos morais, quando ínfimo ou exagerado. Hipótese, todavia, em que a verba indenizatória, consideradas as circunstâncias de fato da causa, foi 
como mero incômodo, mesmo dissabor, como no caso de um inadimplemento contratual) ${ }^{58}$. Mas do fato humilhação, parece que não fugimos, quando da prova do dano imaterial, para as relações entre os cônjuges, como visto pela decisão ora comentada. Inclusive, Anderson Schreiber, acerca do critério da dor para a reparabilidade do dano imaterial, pondera que "[...] a dor não representa elemento ontológico do dano moral, mas puro reflexo consequencialísitico, que pode se manifestar ou não, sem que isso elimine o fato da lesão a um interesse extrapatrimonial" 59.

Resta difícil se estabelecer um limite para a violação da fidelidade recíproca enquanto fato ofensivo a direitos da personalidade, caso um fato isolado (humilhação) tenha de vir comprovado. Entretanto, entendemos que a situação de negação à condição de cônjuge, que se encerra pela nefasta e sorrateira surpresa (violação ao dever de fidelidade) é que deve ser ponderada em termos de interesses dos cônjuges.

Mafalda Miranda Barbosa ensina sobre a responsabilidade perante o outro, que então só encontrará condições de operacionalização, quando se analisa e exige a responsabilidade pelo outro ${ }^{60}$. E mais:

\begin{abstract}
Esta responsabilidade pelo outro não resulta, apenas, de um especial estatuto ou cargo que o sujeito ocupe, ou de um acordo entre eles firmado, mas do simples facto de ser pessoa e de, por isso, ter de assumir especiais deveres de precaução (deveres no tráfego) para com o seu próximo. E se alguns desses deveres podem ser consagrados pelo legislador ou decorrer da atividade encabeçada pelo pretenso lesante, não é menos verdade que podem avultar em concreto por referência às exigências que a relação intersubjetiva patenteia. ${ }^{61}$
\end{abstract}

E segue:
Do ponto de vista do titular de um direito subjetivo que, com a sua atuação, lesa um terceiro, a ilicitude colima-se no mau uso da sua liberdade e apresenta um figurino eticamente cunhado que nos autoriza a encontrar para a responsabilidade civil um

estabelecida pela instância ordinária em conformidade com os princípios da proporcionalidade e razoabilidade. 4. Agravo interno a que se nega provimento. (BRASIL. Superior Tribunal de Justiça. Agravo em Recurso Especial $n^{\circ}$ 1729914/DF. Relatora: Ministra Maria Isabel Gallotti. Quarta Turma. Julgado em: 19/04/2021, DJe 23/04/2021).

58 Ementa: AGRAVO INTERNO NO AGRAVO EM RECURSO ESPECIAL. COMPRA E VENDA DE IMÓVEL. ATRASO NA ENTREGA DO IMÓVEL. MERO INADIMPLEMENTO CONTRATUAL. DANO MORAL NÃO CONFIGURADO. SÚMULA 7 DO STJ. AGRAVO INTERNO NÃO PROVIDO. 1. Esta Casa possui entendimento sedimentado no sentido de que, em regra, o atraso na entrega do imóvel constitui mero inadimplemento contratual o que, por si só, não gera dano moral indenizável. 2. A alteração da premissa firmada pela instância ordinária de que o atraso na entrega do imóvel não ultrapassou o mero dissabor, exigiria o revolvimento de suporte fáticoprobatório dos autos, o que é inviável na sede estreita do recurso especial, a teor do que dispõe a Súmula 7 do Superior Tribunal de Justiça. 3. Agravo interno não provido. (BRASIL. Superior Tribunal de Justiça. Agravo em Recurso Especial $n^{\circ}$ 1760992/SP. Relator: Ministro Luis Felipe Salomão. Quarta Turma. Julgado em: 26/04/2021, DJe 28/04/2021).

59 SCHREIBER, Anderson. Novos paradigmas da responsabilidade civil: da erosão dos filtros à diluição dos danos. 5. ed. São Paulo: Atlas, 2013, p. 131.

60 BARBOSA, Mafalda Miranda. Do sentido da responsabilidade aos sentidos da responsabilidade: da role responsibility à liability; a responsabilidade contratual e a responsabilidade patrimonial. Revista de Direito da Responsabilidade, Coimbra, ano 2, 2020. Disponível em: https://revistadireitoresponsabilidade.pt/2020/dosentido-da-responsabilidade-mafalda-miranda-barbosa. Acesso em: 07 jun. 2021.

61 BARBOSA, Mafalda Miranda. Entre a ilicitude e o dano. Revista de Direito da Responsabilidade, Coimbra, ano 1, 2019. Disponível em: https://revistadireitoresponsabilidade.pt/2019/entre-a-ilicitude-e-o-dano/ Acesso em: 07 jun. 2021. 
fundamento sancionatório que, não se confundindo com uma função punitiva, visa atualizar a pessoalidade do agente perpetrador do ato. ${ }^{62}$

Menezes Cordeiro pondera que, se por um lado "A ampliação dos fins da responsabilidade civil, vem a relativizar o dano e flexibilizar indemnização”, não pode, por outra mão, diminuí-la: ou seja, muito pelo contrário ${ }^{63}$.

As lições de Ingo Wolfgang Sarlet caem como uma luva ao o que sustentamos ao longo da exposição:

Com efeito, diante do compromisso assumido formalmente pelo Constituinte, pelo menos - nas hipóteses de violação dos deveres e direitos decorrentes da dignidade da pessoa - restará uma perspectiva concreta, ainda que mínima, de efetivação por meio dos órgãos jurisdicionais, enquanto e na medida em que se lhes assegurar as condições básicas para o cumprimento de seu desiderato. ${ }^{64}$

Yussef Said Cahali entende inexistir dúvidas sobre a ocorrência do ato ilícito quando configurada grave infração aos deveres conjugais, pois aquele ato, segundo o entendimento do mestre, "[...] preserva sua autonomia, ainda que projetados duplamente os seus efeitos: como representativos dos deveres conjugais, posto como causa da dissolução do casamento e como causa da responsabilidade civil da regra geral do art. 186 do Código" 65.

Flaviana Rampazzo Soares, lecionando sobre a responsabilidade aquiliana, aduz que aquela "[...] fundamenta-se nos deveres genéricos de não lesar e de que as pessoas não experimentem danos juridicamente inaceitáveis, servindo como meio lenitivo ou repristinatório à vítima" 66 . O não lesar, trazido pela ilustre professora, em nosso entendimento, encontra eco na observação ao dever que aqui trouxemos e o colocamos no microscópio.

Para aferição do dano, vimos que objetivamente o que se analisa é a lesão à dignidade da pessoa, em sua existencialidade, portanto, de forma constitucional, julgar procedente o pedido de danos imateriais apenas com base no fato humilhação, constrangimento, com todo o respeito, não resolve a questão.

Justamente por haver um núcleo mínimo, mas fundamental, previsto constitucionalmente, como a proteção da família e de seus integrantes, como a reparação de danos imateriais, sendo que,

62 BARBOSA, Mafalda Miranda. Do sentido da responsabilidade aos sentidos da responsabilidade: da role responsibility à liability; a responsabilidade contratual e a responsabilidade patrimonial. Revista de Direito da Responsabilidade, Coimbra, ano 2, 2020. Disponível em: https://revistadireitoresponsabilidade.pt/2020/dosentido-da-responsabilidade-mafalda-miranda-barbosa. Acesso em: 07 jun. 2021.

${ }^{63}$ MENEZES CORDEIRO, António. Tratado de direito civil português: direito das obrigações: tomo III: gestão de negócios: enriquecimento sem causa: responsabilidade civil. v. II. Coimbra: Almedina, 2010, p. 747.

64 SARLET, Ingo Wolfgang. Dignidade (da pessoa) humana e direitos fundamentais na Constituição Federal de 1988. 10. ed. Porto Alegre: Livraria do Advogado, 2019, p. 28.

65 CAHALI, Yussef Said. Dano moral. 4. ed. São Paulo: Revista dos Tribunais, 2011, p. 588-589.

66 SOARES, Flaviana Rampazzo. Revisitando o dilema responsabilidade contratual versus responsabilidade aquiliana. Revista IBERC, Belo Horizonte, v. 4, n. 2, p. IV-XIII, maio/ago. 2021, p. 7. 
por sua vez, o Código Civil impõe o dever de fidelidade recíproca, sua violação tem sim cunho de ofensa a direitos da personalidade do cônjuge, de forma objetiva, eis que sua valoração, enquanto pessoa humana e cônjuge, é desvirtuada pelo ofensor. É negar, portanto, seu cônjuge, como parceiro (a) em um projeto familiar de vida, em retidão, em uma caminhada pela vida que é regida por núcleos mínimos, formados pela afetividade enquanto princípio, e também pelo respeito,

Como magistralmente ensina Giselda Maria Fernandes Novaes Hironaka, houve um hiato de cerca de cem anos entre o Código Beviláqua e o Código Miguel Reale, que justificaram modificações sensíveis na legislação relativa à Responsabilidade Civil67. E a dignidade da pessoa, modestamente dizemos, deve ser sempre objeto de análise e de proteção, em uma escala evolutiva, também entre os cônjuges e suas condutas respectivas a um e outro integrante da relação.

A decisão analisada separa a ofensa a direitos de personalidade, ou seja, o momento da violação: não ocorre pelo descumprimento do dever, mas, sim, de uma eventual conduta do ofensor que coloque o cônjuge em situação de humilhação, como visto. Daí entendermos como extra causa a violação a direitos de personalidade. O que, por outro lado, pensamos que deve vir um juízo pautado pela existenciliadade do cônjuge protegida constitucionalmente, em atenção ao princípio da dignidade, de forma concreta.

O tempo e sua valorização, para o Direito, vem sendo objeto de sérios estudos e reflexões. Do mesmo modo o seu menosprezo, como ensinam Claudia Lima Marques e Bruno Miragem: "Nem a perda do tempo mediante estratégias organizadas do fornecedor pode ser mais qualificada como "mero dissabor", nem o tempo que alguém se dispõe a investir nas relações e afeto" 68 .

Sobre o tempo e o investimento em determinada relação (por nossa conta e risco), exigir a prova cabal de uma situação fora do que se entende por normal para dentro das relações entre casais, em termos do descumprimento do dever de fidelidade recíproca, entendemos, é por demais penoso ao cônjuge ofendido. Não se trata de algo decorrente daquelas relações e assim e que deveria permanecer: trata-se, a ofensa à fidelidade, de uma negativa geral da própria existência da condição de cônjuge.

Os casais se conhecem; fazem planos; muitas vezes, um dos integrantes abre as portas de seu lar para que o outro seja acolhido: configuram verdadeira família no plano constitucional e infraconstitucional. Depositam esperanças, expectativas e, em dado momento, há a nefasta surpresa ocasionada pelo descumprimento do dever de fidelidade. Entra em cena, também, a violação à boa-fé objetiva, que poder funcionar como possível fonte do dever de reparação, como já sustentamos recentemente ${ }^{69}$.

${ }^{67}$ HIRONAKA, Giselda Maria Fernandes Novaes. Responsabilidade pressuposta: evolução de fundamentos e de paradigmas da responsabilidade civil na contemporaneidade. In: HIRONAKA, Giselda Maria Fernandes Novaes; FALAVIGNA, Maria Clara Osuna Diaz (Org.). Ensaios sobre responsabilidade civil nas pós-modernidade. Porto Alegre: Magister, 2007, p. 156.

${ }^{68}$ MARQUES, Claudia Lima; MIRAGEM, Bruno. O novo direito privado e a proteção dos vulneráveis. São Paulo: Revista dos Tribunais, 2012, p. 205.

${ }^{69}$ ALMEIDA, Felipe Cunha de. Violação à boa-fé objetiva nas relações familiares como possível fonte do dever de reparação. In: TEIXEIRA, Ana Carolina Brochado; ROSENVALD, Nelson; MULTEDO, Renata Vilela (Coord.). 
Se o entendimento vier única e exclusivamente no sentido de uma situação subjetiva em termos de comprovação de humilhação, entendemos que a violação à fidelidade recíproca, enquanto constitucionalmente inserida em respeito à dignidade do cônjuge, a reparação verá na humilhação a extra causa que estamos alertando, expressão que trouxemos no título destes comentários, e não enquanto lesão objetiva a interesses da pessoa humana enquanto ser que existe e integra determinada relação familiar.

À luz da ratio das normas estudadas nestas linhas, ponderamos que a finalidade da lei é primar por um fundamento constitucional familiar e, quando quebrado, a dignidade humana da pessoa enquanto valor, enquanto brilho que tem, resta violada. De sorte que, aprofundando hoje o que dissemos em outra ocasião ${ }^{70}$, a família deve ser respeitada e ser fator de desenvolvimento e crescimento da personalidade, e não ficar de portas fechadas ao respeito e valorização dos seus integrantes, o que impõe sim ao dever de fidelidade, quando violado, uma interpretação de quebra da existencialidade do cônjuge ofendido, eis que integrante da família, vendo suas aspirações, projetos, entrega ao outro, ver seu direito de felicidade ser respeitado, por exemplo, encerrados, de forma objetiva. Não que não exista um sentimento de amargura, de humilhação, contudo, objetivamente, é que entendemos, com base nos ensinamentos da doutrina trazidos, que há nexo de causalidade mínimo entre a violação do dever de fidelidade e a lesão a direitos de personalidade.

É evidente que os relacionamentos podem ter um fim; podem chegar ao desgaste, contudo, tal premissa não autoriza o desvalor, o desprezo e o apequenamento do (a) outro (a) integrante da relação, pelo descumprimento abrupto, pensado (ou, mesmo que em uma atitude imprudente). Vejam: ao se pensar assim, em especial na conduta daquele que descumpriu com o ordenamento, vamos voltar passos importantes, retroceder a um sistema de Responsabilidade Civil puramente preocupado com o autor do dano, e não com a vítima.

Não podemos confundir, portanto, "um não dar certo", com a pessoa humana em si, como objeto deste "não dar certo". São situações absolutamente distintas, eis que, quanto à primeira, estamos diante dos fatos naturais de uma vida em comum, mesmo que com certa dor. E, neste aspecto, certamente entram as valiosas lições de Humberto Theodoro Júnior, quando analisa o dever de reparação por danos imateriais: "[...] não será suficiente ao ofendido demonstrar sua dor. Somente ocorrerá a responsabilidade civil se se reunirem todos os seus elementos essenciais; dano, ilicitude e nexo causal" 71 .

Anderson Schreiber ensina sobre o método de aferição do dano, sendo, por nossa conta e risco, também fundamento para a defesa do tema proposto nestes comentários. O mestre em referência apresenta duas fases:

Responsabilidade civil e direito de família: o direito de danos na parentalidade e conjugalidade. Indaiatuba: Foco, 2021.

${ }_{70}$ ALMEIDA, Felipe Cunha de. Responsabilidade civil no direito de família: angústias e aflições das relações familiares. 2. ed. Porto Alegre: Livraria do Advogado: 2019, p. 187-218.

71 THEODORO JÚNIOR, Humberto. Dano moral. 8. ed. Rio de Janeiro: Forense, 2016, p. 6. 
[...] a primeira, em que se verifica o merecimento da tutela em abstrato dos interesses conflitantes; a segunda, em que não havendo prevalência estipulada entre dois interesses tutelados (por receberam ambos, em abstrato, proteção de igual patamar), confere-se ao juiz um espaço de ponderação para que decida qual interesse deve prevalecer à luz das circunstâncias concretas. ${ }^{72}$

A primeira fase, segue o jurista, consiste em encontrar certa norma (específica ou geral) que tenha relação com o merecimento da tutela do interesse lesado ${ }^{73}$. De sorte que aquela etapa "[...] terá influência em passo posterior da aferição do dano, que diz respeito ao estabelecimento da regra de prevalência frente ao interesse conflitante" ${ }^{74}$. A etapa seguinte consiste na verificação em se "[...] o interesse representado pela conduta lesiva é igualmente merecedor de tutela" 75.

A conclusão que nos apresenta Anderson Schreiber vem no sentido de que:

[...] as mesmas normas genéricas que são invocadas para sustentar a reparabilidade de um dano existencial efêmero podem também ser invocadas para sustentar a legitimidade de um comportamento que provoca o dano.

Assim, se o direito de imagem pode amparar a vítima, a liberdade de expressão pode socorrer quem pratica a conduta lesiva, revelando que, no atual cenário normativo, excluir, em abstrato, o merecimento de tutela do interesse lesivo torna-se tão difícil quanto excluir, em abstrato, o merecimento de tutela de certo interesse lesado. ${ }^{76}$

Mas o mestre em referência faz a seguinte ressalva aos ensinamentos supratranscritos "exceção a estas constatações ocorre no caso de condutas especificamente proibidas" 77. É que não há, para esta hipótese, de merecimento à tutela em termos de interesse ${ }^{78}$.

Cristiano Chaves de Farias, Felipe Peixoto Braga Netto e Nelson Rosenvald nos ensinam, por sua vez, sobre o balanceamento de interesses "[...] evidenciam-se também hipóteses de atos lícitos que geram a obrigação de indenizar, por não ser razoável manter a vítima sem ressarcimento, ao balancearmos os interesses do lesante e do lesado" 79.

72 SCHREIBER, Anderson. Novos paradigmas da responsabilidade civil: da erosão dos filtros à diluição dos danos. 5. ed. São Paulo: Atlas, 2013, p. 164.

73 SCHREIBER, Anderson. Novos paradigmas da responsabilidade civil: da erosão dos filtros à diluição dos danos. 5. ed. São Paulo: Atlas, 2013, p. 164.

${ }^{74}$ SCHREIBER, Anderson. Novos paradigmas da responsabilidade civil: da erosão dos filtros à diluição dos danos. 5. ed. São Paulo: Atlas, 2013, p. 164.

75 SCHREIBER, Anderson. Novos paradigmas da responsabilidade civil: da erosão dos filtros à diluição dos danos. 5. ed. São Paulo: Atlas, 2013, p. 165.

${ }^{76}$ SCHREIBER, Anderson. Novos paradigmas da responsabilidade civil: da erosão dos filtros à diluição dos danos. 5. ed. São Paulo: Atlas, 2013, p. 165.

${ }^{77}$ SCHREIBER, Anderson. Novos paradigmas da responsabilidade civil: da erosão dos filtros à diluição dos danos. 5. ed. São Paulo: Atlas, 2013, p. 165.

78 SCHREIBER, Anderson. Novos paradigmas da responsabilidade civil: da erosão dos filtros à diluição dos danos. 5. ed. São Paulo: Atlas, 2013, p. 165.

79 FARIAS, Cristiano Chaves de; BRAGA NETTO, Felipe Peixoto; ROSENVALD, Nelson. Novo tratado de responsabilidade civil. São Paulo: Atlas, 2015, p. 237. 
Continuando, a análise também passa pela existência de norma de prevalência entre os interesses conflitantes. Aqui, quando do confronto entre a conduta lesiva em conjunto com o interesse merecedor da tutela, "[...] cumpre verificar se o legislador estabeleceu, de alguma forma, uma regra de prevalência entre os dois interesses conflitantes" ${ }^{80}$. Para a hipótese de inexistência de uma regra de prevalência, caberá ao Poder Judiciário buscar a ponderação dos interesses em conflitos, "[...] definindo a relação de prevalência entre eles, com base na leitura das circunstâncias concretas à luz do ordenamento jurídico" 81 .

A humilhação exigida no recurso analisado nos permite concluir que se traduz em causa isolada da reparação de danos imateriais, reparação esta que está fora dos limites da violação ao dever de fidelidade recíproca. Ainda, quando de tal entendimento trazido pela Corte, não se mostra nem possível avaliar a humilhação como concausa, está que, nas palavras de Sergio Cavalieri Filho: "[...] é outra causa que, juntando-se à principal, concorre para o resultado. Ela não é única e nem interrompe o nexo causal, apenas o reforça, tal como um rio menor que deságua em outro maior, aumentando-lhe o caudal" 82 .

Ora, se Maria Helena Diniz aduz que:

O comportamento do agente será reprovado ou censurado quando, ante as circunstâncias concretas do caso, se ele entende que ele poderia ou deveria ter agido de modo diferente. Portanto, 0 ato ilícito qualifica-se pela culpa. ${ }^{83}$

Se na hipótese de se levar com rigorismo exagerado a violação do dever de fidelidade recíproca, a depender de prova de humilhação, entendemos que o valor inerente aos direitos da personalidade, como leciona Maria Celina Bodin de Moraes, a título de situações existenciais, restará ofendido enquanto valor fundamental de nossa ordem jurídica ${ }^{84}$.

Dependendo das consequências que o descumprimento ocasionar, é de se cogitar que a vítima não irá mais pensar em entrar em um relacionamento sério. É verdade, não temos dados estatísticos acerca desta hipótese. Contudo e inspirados no Código de Processo Civil, as regras ordinárias de experiência sustentam este raciocínio ${ }^{85}$. Inclusive, Pontes de Miranda observa que, mesmo antes ou depois da sentença, "[...] se o dano cresce ou decresce, não se pode considerar o

${ }^{80} \mathrm{SCHREIBER}$, Anderson. Novos paradigmas da responsabilidade civil: da erosão dos filtros à diluição dos danos. 5. ed. São Paulo: Atlas, 2013, p. 166.

${ }^{81} \mathrm{SCHREIBER}$, Anderson. Novos paradigmas da responsabilidade civil: da erosão dos filtros à diluição dos danos. 5. ed. São Paulo: Atlas, 2013, p. 168.

82 CAVALIERI FILHO, Sergio. Programa de responsabilidade civil. 11. ed. São Paulo: Atlas, 2014, p. 78.

${ }^{83}$ DINIZ, Maria Helena. Curso de direito civil brasileiro: responsabilidade civil. v. 7. 29. ed. São Paulo: Saraiva, $2015, \mathrm{p} 57$.

${ }^{84}$ MORAES, Maria Celina Bodin de. Danos à pessoa humana: uma leitura civil-constitucional dos danos morais. 2. ed. Rio de Janeiro: Processo, 2017, p. 121.

${ }^{85} \mathrm{Art}$. 375. O juiz aplicará as regras de experiência comum subministradas pela observação do que ordinariamente acontece e, ainda, as regras de experiência técnica, ressalvado, quanto a estas, o exame pericial. 
pedido como restrito ao que consta na inicial e indilatável" ${ }^{86}$. De sorte que o juiz, ao decidir, deve levar em conta as possibilidades para o futuro, em decorrência do dano ${ }^{87}$.

Pietro Perlingieri nos diz que a proteção da pessoa, enquanto dotada de direitos da personalidade, deve ser interpretada (a pessoa, por tanto), como um todo unitário à luz da palavra valor ${ }^{88}$.

Como diz Francisco Amaral "justifica-se, portanto, o direito na sua existência e nos seus efeitos, pela realização dos valores que a sociedade estabelece como finalidade básica do ordenamento jurídico e que, por isso mesmo, lhe servem de fundamento" ${ }^{89}$. Esta premissa, entendemos, deve ser objeto de aplicação à proteção à dignidade quando da violação do dever de fidelidade recíproca, pois afronta diretamente a personalidade do cônjuge, com destaque, insistimos, novamente, para a pessoa e a Constituição ${ }^{90}$.

Talvez o estudioso pense na seguinte pergunta: "mas afinal, colocando em um microscópio a violação ao dever de fidelidade recíproca, e o isolando da necessidade de comprovação da humilhação, o que, efetivamente haveria de ser reparado, em sede de compensação em quantia, a título de danos imateriais? Bem, nossa resposta vem no sentido de que tal violação, encarada de forma objetiva, encontra fundamento na negação da condição existencial do cônjuge vítima do descumprimento, bem como por não poder mais suportar a vida em comum, em ver então um projeto de vida interrompido, finalizado e sepultado pela ação do (a) outro (a). Assim e voltando ao título dos comentários ao recurso trazido, a humilhação não pode ser analisada como condição sem a qual a reparação, mirando a proteção da dignidade do cônjuge, como extra e isolada causa, para fins de compensação, exigira. A humilhação, se houver, é fato a ser analisado e relevado à luz da quantificação do dano; junta-se à violação aos direitos da personalidade neste sentido.

Entendemos, portanto e com base na lógica acima, que tal caminho hermenêutico vem a propiciar sim a incidência da Responsabilidade Civil no Direito de Família, pois a violação do dever de fidelidade recíproca, como visto, é ofensiva à dignidade da pessoa humana do cônjuge, como já fundamentado. Não se trata, é bom que se diga, de incentivo às demandas judiciais da natureza trazida, mas, sim, de incentivo ao respeito mínimo da condição, existencialidade e interesse constitucional do outro enquanto ser integrante de um projeto individual e ao mesmo tempo familiar, de um ser humano para a própria família, projeto encerrado, sem sua participação, encerrado pelo ofensor.

${ }^{86}$ PONTES DE MIRANDA, Francisco Cavalcanti. Tratado de direito privado: parte especial: tomo 53. 1. ed. Atualizado por Vilson Rodrigues Alves. Campinas: Bookseller, 2008, p. 324-325.

${ }^{87}$ PONTES DE MIRANDA, Francisco Cavalcanti. Tratado de direito privado: parte especial: tomo 53. 1. ed. Atualizado por Vilson Rodrigues Alves. Campinas: Bookseller, 2008, p. 325.

88 PERLINGIERI, Pietro. Perfis do direito civil: introdução ao direito civil constitucional. 3. ed. Tradução de Maria Cristina De Cicco. Rio de Janeiro: Renovar, 2007, p. 156.

${ }^{89}$ AMARAL, Francisco. Direito civil: introdução. 10. ed. São Paulo: Saraiva Educação, 2018, p. 61.

${ }^{90}$ Art. $1^{\circ} \mathrm{A}$ República Federativa do Brasil, formada pela união indissolúvel dos Estados e Municípios e do Distrito Federal, constitui-se em Estado Democrático de Direito e tem como fundamentos:

[...]

III - a dignidade da pessoa humana; 
O enfoque da ação de reparação deve ser entendido, em termos de causa de pedir e pedido, para além de sentimentos subjetivos. Deve, gostaríamos de acentuar, mirar a condição humana de quem resolve acolher o (a) outro (a) para, unindo, respeitando e mantendo as individualidades, ver formada verdadeira família.

\section{REFERÊNCIAS}

ALMEIDA, Felipe Cunha de. Normatividade e interação entre os deveres pessoais do direito de família, as leis imperfeitas e a responsabilidade civil. Revista Eletrônica da ESA/RS, Porto Alegre, v. 8, p. 01$20,2020$.

ALMEIDA, Felipe Cunha de. Responsabilidade civil no direito de família: angústias e aflições das relações familiares. 2. ed. Porto Alegre: Livraria do Advogado: 2019.

ALMEIDA, Felipe Cunha de. Violação à boa-fé objetiva nas relações familiares como possível fonte do dever de reparação. In: TEIXEIRA, Ana Carolina Brochado; ROSENVALD, Nelson; MULTEDO, Renata Vilela (Coord.). Responsabilidade civil e direito de família: o direito de danos na parentalidade e conjugalidade. Indaiatuba: Foco, 2021.

AMARAL, Francisco. Direito civil: introdução. 10. ed. São Paulo: Saraiva Educação, 2018.

AZEVEDO, Antônio Junqueira de. Caracterização jurídica da dignidade da pessoa humana. Revista dos Tribunais, São Paulo, ano 91, v. 797, mar. 2002.

BARBOSA, Mafalda Miranda. Causalidade mínima. Revista de Direito da Responsabilidade, Coimbra, ano 1, 2019. Disponível em: http://revistadireitoresponsabilidade.pt/2019/causalidade-minima. Acesso em: 07 jun. 2021.

BARBOSA, Mafalda Miranda. Do sentido da responsabilidade aos sentidos da responsabilidade: da role responsibility à liability; a responsabilidade contratual e a responsabilidade patrimonial. Revista de Direito da Responsabilidade, Coimbra, ano 2, 2020. Disponível em: https://revistadireitoresponsabilidade.pt/2020/do-sentido-da-responsabilidade-mafalda-mirandabarbosa. Acesso em: 07 jun. 2021.

BARBOSA, Mafalda Miranda. Entre a ilicitude e o dano. Revista de Direito da Responsabilidade, Coimbra, ano 1, 2019. Disponível em: https://revistadireitoresponsabilidade.pt/2019/entre-a-ilicitude-eo-dano/ Acesso em: 07 jun. 2021.

BRASIL. Superior Tribunal de Justiça. Agravo Interno no Agravo no Recurso Especial $n^{\circ} 1673702 / S P$. Relatora: Ministra Maria Isabel Gallotti. Quarta Turma, julgado em 14/09/2020, DJe 18/09/2020. Disponível em: http://www.stj.jus.br. Acesso em: 07 jun. 2021.

BRASIL. Código Civil. Lei n. 10.406, de 10 de janeiro de 2002. DF, 01 jan. 2002. Disponível em: http://www.planalto.gov.br/ccivil_03/LEIS/2002/L10406.htm.

BRASIL. Código de Processo Civil. Lei no 13.105, de 16 de março de 2015. DF, 16 mar. 2015. Disponível em: http://www.planalto.gov.br/ccivil_03/_Ato2015-2018/2015/Lei/L13105.htm. Acesso em: 07 jun. 2021.

BRASIL. Constituição da República Federativa do Brasil de 1988. DF, 05 outubro de 1988. Disponível em: http://www.planalto.gov.br/ccivil_03/Constituicao/Constituicao.htm. Acesso em: 07 jun. 2021.

BRASIL. Superior Tribunal de Justiça. Decisão monocrática. REsp 1887568. Rel. Min: Moura Ribeiro. Publicado em: 21/08/2020. Disponível em: https://processo.stj.jus.br/processo/dj/documento/mediado/?tipo_documento=documento\&component 
e=MON\&sequencial=113964693\&tipo_documento=documento\&num_registro=202001946236\&data= 20200821\&formato=PDF. Acesso em: 07 jun. 2021.

BRASIL. Superior Tribunal de Justiça. Quarta Turma. AgInt no AREsp 1729914/DF. Rel. Min: Maria Isabel Gallotti. Julgado em: 19/04/2021. Disponível em: https://scon.stj.jus.br/SCON/GetInteiroTeorDoAcordao?num_registro=202001756189\&dt_publicacao= 23/04/2021. Acesso em: 07 jun. 2021.

BRASIL. Superior Tribunal de Justiça. Quarta Turma. AgInt no AREsp 1760992/SP. Rel. Mini: Luis Felipe Salomão. Julgado em: 26/04/2021. Disponível em: https://scon.stj.jus.br/SCON/GetInteiroTeorDoAcordao?num_registro=202002413346\&dt_publicacao= 28/04/2021. Acesso em: 07 jun. 2021.

BRASIL. Superior Tribunal de Justiça. Quarta Turma. REsp 343.700/PR. Rel. Min: Ruy Rosado de Aguiar. Julgado em: 09/04/2002. Disponível em: https://scon.stj.jus.br/SCON/GetInteiroTeorDoAcordao?num_registro=200101036811\&dt_publicacao= 0. Acesso em: 07 jun.2021.

BRASIL. Superior Tribunal de Justiça. Segunda Turma. AgInt no AREsp 1673702/SP. Rel. Min: Maria Isabel Gallotit. Julgado em 14/09/2020. Disponível em: https://scon.stj.jus.br/SCON/GetInteiroTeorDoAcordao?num_registro=202000515906\&dt_publicacao= 18/09/2020. Acesso em: 07 jun. 2021.

BONAVIDES, Paulo. Curso de direito constitucional. 33. ed. São Paulo: Malheiros, 2018.

CAHALI, Yussef Said. Dano moral. 4. ed. São Paulo: Revista dos Tribunais, 2011.

CAVALIERI FILHO, Sergio. Programa de responsabilidade civil. 11. ed. São Paulo: Atlas, 2014.

DE CUPIS, Adriano. Os direitos da personalidade. 2. ed. Tradução de Afonso Celso Furtado Rezende. São Paulo: Quorum, 2008.

DINIZ, Maria Helena. Curso de direito civil brasileiro: responsabilidade civil. v. 7. 29. ed. São Paulo: Saraiva, 2015.

FARIAS, Cristiano Chaves de; BRAGA NETTO, Felipe Peixoto; ROSENVALD, Nelson. Novo tratado de responsabilidade civil. São Paulo: Atlas, 2015.

GAGLIANO, Pablo Stolze; PAMPLONA FILHO, Rodolfo. Novo curso de direito civil: parte geral. v. 1.16. ed. São Paulo: Saraiva, 2014.

GAGLIANO, Pablo Stolze; PAMPLONA FILHO, Rodolfo. Novo curso de direito civil: responsabilidade civil. v. 3. 13. ed. São Paulo: Saraiva, 2015.

GOMES, Orlando. Direito de família. 7. ed. Rio de Janeiro: Forense, 1993.

HIRONAKA, Giselda Maria Fernandes Novaes. Responsabilidade pressuposta: evolução de fundamentos e de paradigmas da responsabilidade civil na contemporaneidade. In: HIRONAKA, Giselda Maria Fernandes Novaes; FALAVIGNA, Maria Clara Osuna Diaz (Org.). Ensaios sobre responsabilidade civil nas pós-modernidade. Porto Alegre: Magister, 2007.

ITURRASPE, Jorge Mosset. Responsabilidade por daños: el dano moral. Tomo V. Buenos Aires: Rubinzal-Culzoni Editores, 1971.

LÔBO, Paulo. Direito civil: famílias. v. 5. 9. ed. São Paulo: Saraiva Educação, 2019.

MARQUES, Claudia Lima; BENJAMIN, Antônio Herman V; BESSA, Leonardo Roscoe. Comentários ao código de defesa do consumidor. 3. ed. São Paulo: Revista dos Tribunais, 2010. 
MARQUES, Claudia Lima; MIRAGEM, Bruno. O novo direito privado e a proteção dos vulneráveis. São Paulo: Revista dos Tribunais, 2012.

MENEZES CORDEIRO, António. Tratado de direito civil português: direito das obrigações: tomo III: gestão de negócios: enriquecimento sem causa: responsabilidade civil. v. II. Almedina, Coimbra, 2010.

MIRAGEM, Bruno. Direito civil: responsabilidade civil. São Paulo: Saraiva, 2015.

MORAES, Maria Celina Bodin de. Danos à pessoa humana: uma leitura civil-constitucional dos danos morais. 2. ed. Rio de Janeiro: Processo, 2017.

NADER, Paulo. Introdução ao estudo do direito. 40. ed. Rio de Janeiro: Forense, 2017.

NORONHA, Fernando. Direito das obrigações. 4. ed. São Paulo: Atlas, 2013.

PEREIRA, Caio Mário da Silva. Instituições de direito civil: introdução ao direito civil: teoria geral do direito civil. v. 01. 29. ed. Atualizado por Maria Celina Bodin de Moraes. Rio de Janeiro: Forense, 2016.

PEREIRA, Caio Mário da Silva. Responsabilidade civil. 10. ed. Atualizado por Gustavo Tepedino. Rio de Janeiro: GZ, 2012.

PERLINGIERI, Pietro. Perfis do direito civil: introdução ao direito civil constitucional. 3. ed. Tradução de Maria Cristina De Cicco. Rio de Janeiro: Renovar, 2007.

PONTES DE MIRANDA, Francisco Cavalcanti. Tratado de direito privado: parte especial: tomo 53. 1. ed. Atualizado por Vilson Rodrigues Alves. Campinas: Bookseller, 2008.

SARLET, Ingo Wolfgang. Dignidade (da pessoa) humana e direitos fundamentais na constituição federal de 1988. 10. ed. Porto Alegre: Livraria do Advogado, 2019.

SCHREIBER, Anderson. In: SCHREIBER, Anderson; TARTUCE, Flávio; SIMÃO, José Fernando; MELLO, Marco Aurélio Bezerra de; DELGADO, Mário Luiz. Código civil comentado: doutrina e jurisprudência. Rio de Janeiro: Forense, 2019.

SCHREIBER, Anderson. Novos paradigmas da responsabilidade civil: da erosão dos filtros à diluição dos danos. 5. ed. São Paulo: Atlas, 2013.

SOARES, Flaviana Rampazzo. Revisitando o dilema responsabilidade contratual versus responsabilidade aquiliana. Revista IBERC, Belo Horizonte, v. 4, n. 2, p. IV-XIII, maio/ago. 2021.

TARTUCE, Flávio. Direito civil: direito das obrigações e responsabilidade civil. v.2. 29. ed. Rio de Janeiro: Forense, 2014.

TEPEDINO, Gustavo; TERRA, Aline Miranda Valverde; GUEDES, Gisela Sampaio da Cruz. Fundamentos do direito civil: responsabilidade civil. v. 4. Rio de Janeiro: Forense, 2020.

THEODORO JÚNIOR, Humberto. Dano moral. 8. ed. Rio de Janeiro: Forense, 2016.

Recebido: 05.08.2021

Aprovado: 20.09.2021

Como citar: ALMEIDA, Felipe Cunha de. Descumprimento do dever de fidelidade recíproca e o julgamento do Aglnt no AREsp 1673702/SP: conclusão da humilhação como isolada e extra causa configuradora do dano imaterial. Revista IBERC, Belo Horizonte, v. 4, n. 3, p. 125-146, set./dez. 2021.

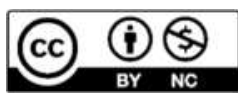

